\title{
Annotated Bibliography of the U.S. Geological Survey Front Range Infrastructure Resources Project-1996-2001
}

by Daniel H. Knepper, Jr. ${ }^{1}$

Open-File Report 01-302

2001

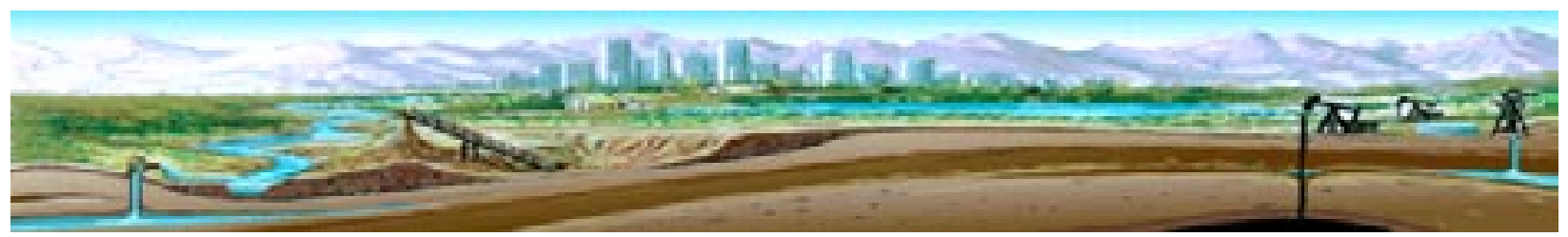

This report is preliminary and has not been reviewed for conformity with U.S. Geological Survey editorial standards or with the North American Stratigraphic Code. Any use of trade, firm, or product names is for descriptive purposes only and does not imply endorsement by the U.S. Government.

U.S. DEPARTMENT OF THE INTERIOR

U.S. GEOLOGICAL SURVEY

${ }^{1}$ Denver, Colorado 


\section{Table of Contents}

This annotated bibliography includes published reports and datasets prepared by scientists working on the Front Range Infrastructure Project between 1996 and 2001. The entries are grouped into the categories below. Reports containing digital datasets are listed under their respective topics as well as under Digital Datasets.

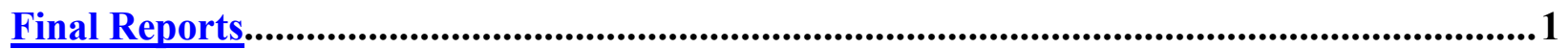

General

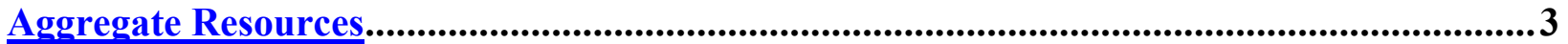

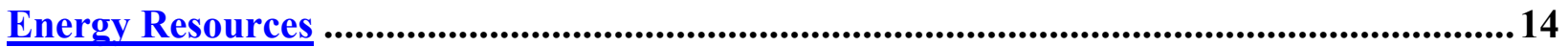

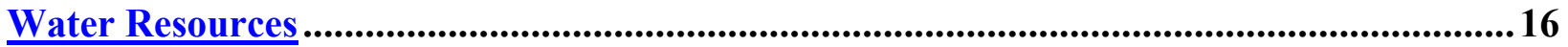

Reclamation, Habitat, and Environment........................................................................... 18

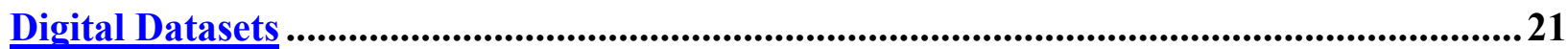




\title{
Front Range Infrastructure Resources Project $1996-2001$
}

\section{Annotated Bibliography}

\section{Final Reports}

USGS Front Range Infrastructure Resources Project, 2001, Planning for the conservation and development of infrastructure resources in urban areas - Colorado Front Range Urban Corridor: U.S. Geological Survey Circular 1219. Available at URL http://greenwood.cr.usgs.gov/pub/circulars/c1219/

\begin{abstract}
This Circular will provide the reader with a basic understanding of the characteristics, location, distribution, and quality of infrastructure resources in the project area. With this understanding, the reader will then explore the many factors that affect the current and future availability of these resources in the project area, including the socioeconomic aspects of the resources and the complexly interwoven individual and collective interests that policymakers, decision-makers, and the public must address. Finally, the reader will learn about past mining reclamation practices in the project area and how innovative reclamation designs that are functional or aesthetically pleasing may actually serve to make local aggregate sources available while helping to preserve or establish development, open space, water storage and recreational facilities, and wildlife habitat.
\end{abstract}

Knepper, D.H., Jr., 2001, Annotated bibliography of the U.S. Geological Survey Front Range Infrastructure Resources Project-1996-2001: U.S. Geological Survey Open-File Report 01302, 25 p. Available at URL http://greenwood.cr.usgs.gov/pub/open-file-reports/ofr-01$\underline{0302 /}$

This annotated bibliography includes published reports and datasets prepared by scientists working on the Front Range Infrastructure Project between 1996 and 2001.

\section{General}

Fishman, N.S., Evans, J.M., Olmstead, R.J., and Langer, W.H., 2000, 3-D image of urban areas and mountains of the northern Front Range, Colorado: U.S. Geological Survey Geologic Investigations Series I-2750-A, 4 page pamphlet, 1 sheet. Available at URL http://greenwood.cr.usgs.gov/pub/i-maps/i-map2750-a/

Over the past 30 years, communities in the Northern Front Range of Colorado have experienced tremendous growth rivaling or surpassing that in other parts of the United States. This growth has challenged businesses as well as city, county, State, and Federal planners to meet the increasing demands for natural resources necessary for growth. Such resources include construction aggregate (stone, sand, and gravel), water, oil, and natural gas. This map will benefit the general public, businesses, and city, county, State and Federal agencies for a variety of purposes. Members of the Front Range Infrastructure Resources Project will use this 3-D image as a base map for companion publications that show the distribution of resources in the northern Front Range urban corridor and the effects of past resource extraction. 
Interagency Working Group on Industrial Ecology, Material and Energy Flows, 1999, Materials: Washington, D.C., November 1999, 29 p.

The USGS was a principal contributor to this publication. The document is built on a simple premise: understanding how and why we use materials and energy can help us use them more efficiently. As global production increases, we need to do more with less, producing the goods and services we need as a society with less energy, fewer materials, and reduced environmental impact, while leaving more natural resources available for future generations. This report provides a brief history of materials, summarizes their use today, and illustrates a number of ways to use materials more effectively. The report is illustrative, not exhaustive, and ends with a summary of activities the Federal government can undertake, alone or in partnership with others, to facilitate a greater understanding of materials and approaches to their more efficient use.

Langer, W.H., Arbogast, B.F., Knepper, D.H., Jr., Lindsey, D.A., Nealey, L.D., and Roelle, J.E., 1997, U.S. Geological Survey Front Range Infrastructure Resources Project: Proceedings, 5th Annual Symposium, International Center for Aggregates Research, University of Texas at Austin, p. E2-1-1-E2-1-8.

The U.S. Geological Survey has initiated the Front Range Infrastructure Resources Project to collect, compile, and analyze new and existing data on aggregate, water, and energy resources along the Front Range from Pueblo, Colorado, to Cheyenne, Wyoming. Aggregate resources of the Front Range are extremely abundant; however, they are not always close to markets, they may not meet exacting specifications required for specific uses, and their availability may be limited by environmental controls or land-use conflicts. Meeting future demands for aggregate at reasonable prices in the Front Range requires understanding the availability and quality of aggregate. Existing geologic maps will be compiled to determine the areal occurrence of aggregate resources, and models, when used for predictive purposes, will relate resource occurrence to quality, quantity, and availability based on environmental and land-use impacts.

Langer, W.H., Fishman, N.S., Knepper, D.H., Jr., Lindsey, D.A., Mladinich, C.S., Nealey, L.D., Robson, S.G., Roelle, J.E., and Wilburn, D.R., 1999, The Front Range Infrastructure Resources Project - An overview, in Proceedings of the U.S. Geological Survey Front Range Infrastructure Resources Project Stakeholder's Meeting, 4 November 1998: U.S. Geological Survey Open-File Report 99-001, p. 2-3.

The principal goals of the U. S. Geological Survey Front Range Infrastructure Resources Project (FRIRP) are to develop information, define tools, and demonstrate ways to 1) implement a multidisciplinary evaluation of the distribution and quality of a region's infrastructure resources, 2) identify issues that may affect availability of resources, and 3) provide (by working with cooperators) decision makers with tools to evaluate alternatives so as to enhance decision making. The goals of the FRIRP are being implemented through 1) a three-year study of a demonstration area in the northern Colorado Front Range urban corridor; and 2) an overlapping, five-year study of the entire Rocky Mountain Front Range urban corridor from Cheyenne, Wyoming, to Pueblo, Colorado; the objectives will be pursued in conjunction with State and local groups.

\section{U.S. Geological Survey, 1998, Proceedings of the U.S. Geological Survey Front Range Infrastructure Resources Project Stakeholder's Meeting, 4 November 1998: U.S. Geological Survey Open-File Report 99-001, 42p.}

This volume contains abstracts describing preliminary work that was in progress by project scientists and technicians from various disciplines including geology, hydrology, biology, and land characterization. The objective of the Stakeholder's Meeting was to bring together interested parties to discuss land, aggregate, water, energy, and biological resource availability and quality in the Front Range urban corridor and to demonstrate a decision support system. 


\title{
Aggregate Resources
}

Barnett, Adrienne, and Ellefsen, K.J., 2000, Assessment of the alluvial sediments in the Big Thompson River Valley, Colorado: U.S. Geological Survey Digital Data Series DDS-66, v.1.0. Available at URL http://greenwood.cr.usgs.gov/pub/dds/dds-066/

\begin{abstract}
To obtain subsurface geologic information about the alluvium in the Big Thompson River valley, S-wave refraction data were collected along three roads that cross the valley. The traveltimes were processed to estimate velocities and thickness for a layered-earth model; from these models, three cross sections of the river valley were constructed. A layer of soil 0.2 to $1.5 \mathrm{~m}$ thick covers the river. Beneath the soil, there is one layer of alluvium at some locations and two layers at other locations. For the two westernmost cross sections, the total thickness of the alluvium ranges from about 6 to $10 \mathrm{~m}$ near the center of the valley and from about 2 to $6 \mathrm{~m}$ near the sides of the valley. The easternmost cross section is somewhat more complex than the other two, because it is near the confluence of the Big Thompson and the Little Thompson Rivers. In this cross section, the thickness of the alluvium ranges from about 8 to $10 \mathrm{~m}$ in the southern half of the valley and from about 3 to $13 \mathrm{~m}$ in the northern half. In all three cross sections, the alluvium overlies bedrock, which is the upper transition member of the Pierre Shale.
\end{abstract}

Davenport, J.C., and Langer, W.H., 1998, Estimating Los Angeles degradation value using the Schmidt rebound hammer along the Front Range, Colorado: U.S. Geological Survey Open File Report 98-331, 38p.

This report describes a research study conducted to determine if there are any relationships between field tests of rocks using a Schmidt Rebound Hammer and laboratory tests of rocks using the Los Angeles Degradation test. Results show limestone and andesite have an inverse relationship between the rebound number and the corresponding Los Angeles degradation value. The rebound number does not correlate well with granite, gneiss, quartzite, and sandstone. The Schmidt rebound hammer might be used in tests for crushed-stone mining operations, however, its effectiveness as a predictive tool must be assessed prior to operational use.

Ellefsen, K. J., 2000, pick_sw: A program for interactive picking of s-wave refraction data: U.S. Geological Survey Open-file Report 00-020. Available at URL

http://greenwood.cr.usgs.gov/pub/open-file-reports/ofr-00-0020/

Program 'pick_sw' is used to interactively pick travel times from S-wave refraction data. In addition, the seismograms, the travel times, and the spread can be plotted on the computer screen or printed, in postscript format, in a file. This program was developed because the $\mathrm{S}$-wave refraction method is invaluable in characterizing alluvial deposits.

Ellefsen, K.J., Lucius, J.E., and Fitterman, D.V., 1998, An evaluation of several geophysical methods for characterizing sand and gravel deposits: U.S. Geological Survey Open-File Report 98-221, 26p.

This report summarizes an evaluation of four different geophysical methods that may be used to characterize alluvial sand and gravel deposits. The four methods are time-domain electromagnetic (TEM) soundings, DC resistivity soundings, frequency-domain electromagnetic (FEM) profiling, and ground penetrating radar. All four methods are common and hence are readily available to industry. The goal of the evaluation was to determine the advantages and the limitations of the four different geophysical methods when used to characterize deposits.

Ellefsen, K.J., Lucius, J.E., and Fitterman, D.V., 1999, Geophysics in exploration for sand and gravel, in Johnson, K.S., ed., Proceedings, $34^{\text {th }}$ Forum on the Geology of Industrial Minerals, 2-6 May 1998, Norman, Oklahoma: Oklahoma Geological Survey Circular 102, p. 147-149.

This abstract summarizes the report by Ellefsen and others (1998). 
Ellefsen, K.J., Lucius, J.E., and Fitterman, D.V., 1999, Geophysics in exploration for sand and gravel, in Proceedings of the U.S. Geological Survey Front Range Infrastructure Resources Project Stakeholder's Meeting, 4 November 1998: U.S. Geological Survey Open-File Report 99-001, p. 7-9.

This abstract summarizes the report by Ellefsen and others (1998).

Ellefsen, K. J., Barnett, Adrienne, 2001, An investigation of alluvial sediments using $S$-wave refraction -- A case study, in Symposium on the Application of Geophysics to Engineering and Environmental Problems (SAGEEP), Denver, Colo., 2001, Proceedings: Denver, Colo., Omnipress, CD-ROM, various pagination.

This conference paper summarizes the report by Barnett and Ellefsen (2000).

Herring, J.R., and Nigol, N.K., 1999, Element concentrations and water solubility in waste fines associated with aggregate production in the Front Range of Colorado, in Proceedings of the U.S. Geological Survey Front Range Infrastructure Resources Project Stakeholder's Meeting, 4 November 1998: U.S. Geological Survey Open-File Report 99-001, p. 17-18.

This abstract describes the preliminary results of chemical analyses and water solubility tests to determine if there was potential for the release of geoenvironmentally significant trace elements from fine grained waste material or fresh rock at crushed stone operations along the Front Range south of Golden, Colorado.

Kelley, Thomas, 1998, Crushed Cement Concrete Substitution for Construction Aggregates - A Materials Flow Analysis: U.S. Geological Survey Circular 1177, 15p. Available at URL http:/greenwood.cr.usgs.gov/pub/circulars/c1177/

This study examines the flow of materials used to construct our Nation's roads, highways, and buildings in order to understand the substitution of crushed concrete for natural aggregates. At present, the rate of substitution is less than $0.4 \%$ per year, but the rate is increasing rapidly. The materials flow analysis helps to understand the factors influencing the recycling effort. The report details the data available and where there are important data gaps. It puts in perspective the present rate of recycling while pointing to the great potential for future recycling of construction materials.

Knepper, D.H., Jr., 2001, Factors in predicting alluvial gravel composition using digital geologic map and elevation images: An example from the Colorado Front Range, in Bon, R.L, Riordan, R.F., Tripp, B.T, and Krukowski, S.T., eds., Proceedings of the $35^{\text {th }}$ Forum on Geology of Industrial Minerals - The Intermountain West Forum, Salt Lake City, Utah: Utah Geological Survey Miscellaneous Publication 01-2, p. 15-21.

This paper explores the potential of combining digital geologic map and digital elevation data of a drainage basin to estimate the lithologic composition of downstream alluvial gravels. By applying various weighting factors, estimates of the percentage in the gravel of each lithology exposed in the drainage can be made.

Knepper, D.H., Jr., and Langer, W.H., 1998, Front Range Infrastructure Resources Project Aggregate Resources Activities: U.S. Geological Survey Fact Sheet FS-119-98, 4p. Available at URL http://greenwood.cr.usgs.gov/pub/fact-sheets/fs-0119-98/

This Fact Sheet describes factors affecting aggregate resource availability and on-going USGS activities to provide industry, decision-makers, and the public with aggregate resource information including location, thickness, and quality. 
Knepper, D.H., Jr., Green, G.N., and Langer, W.H., 1999, Lithologic and aggregate attributes for the digital geologic map of Colorado: U.S. Geological Survey Open-File Report 99-29

(CDROM). Available at URL http://greenwood.cr.usgs.gov/pub/open-file-reports/ofr-99$\underline{0029 /}$

The Geologic Map of Colorado (Tweto, 1979) was digitized and imported into ARC/INFO by Green (1992). The polygons containing each of the map units were attributed with a unique identification number for each map unit and the geologic symbol used to identify each unit and its age. To further increase the utility of the digital Geologic Map of Colorado, the digital data set has been reattributed to extend the capability of identifying natural aggregate potential to the entire State and expand the flexibility in searching for more specific lithologic characteristics. Two sets of attributes have been defined for the lithologic units contained on the Geologic Map of Colorado (Tweto, 1979). In addition to the identification number, map unit symbol, and age symbol based on Green (1992), the first set describes the mode of formation, composition, texture, and variability of the mapped units according to descriptions on the Explanation of the Geologic Map of Colorado. The second set estimates the physical and chemical properties of each unit for use as natural aggregate in Portland cement concrete and identifies other known uses of each unit for construction materials.

Langer, W.H., 1997, The history of aggregate development and geology: Aggregates Manager, v.2, no. 6 , p. 35-38.

Most significant events relating to the human use of natural aggregate (crushed stone and sand and gravel) in the United States have taken place in little more than a century and span the era from the use of horse and buggy on dirt roads to superhighways and jet and space travel. Around the beginning of the 20th Century, annual aggregate production in the United States amounted to about 51 million short tons, or about one-half ton per person per year. In less than 100 years, the annual production of aggregate has increased nearly 50 fold to over two billion tons of aggregate, or an average of about 9 tons of aggregate per person per year. The primary drivers in the production of aggregate are demand, changes in technology, and a continually improving understanding of the properties and behavior of aggregate under various uses. The related geologic aspects of aggregate development have evolved with, and in part, controlled the advances in the aggregate industry.

Langer, W.H., 1998, Aggregates History: Aggregates Manager.

This is a series of 12 single-page articles listed below describing the history of the use of natural aggregate (crushed stone and sand and gravel) in the United States.

, Why Should We Examine the Industry's Past?: Aggregates Manager, January, v. 2, no. 10, p. 56.

, America's First Roads are Still Waiting for Highway Funding: Aggregates Manager, February, v. 2, no. 11, p. 67- 68.

, A High "Place Value" Commodity: Aggregates Manager, March, v. 2, no. 12, p. 60. , Long Haul of Aggregates - A New Concept?: Aggregates Manager, April, v. 3, no. 1, p. 70. 58.

, Chemical Problems Related to Use of Aggregate: Aggregates Manager, June, v. 3, no. 3, p. 58.

, Aggregate Prospecting and Characterization: Aggregates Manager, July, v. 3, no. 4, p. 66.

Technical Advances in the Aggregates Industry: Aggregates Manager, August, v. 3, no.

5, p. 62.

Encroachment of Urban Development on Aggregate Operations Can Lead to

Sterilization: Aggregates Manager, September, v. 3, no. 6, p. 58.

, Citizen Opposition to Aggregate Development: Aggregates Manager, October, v. 3, no.

7, p. 56.

, A New Image for the Industry: Aggregates Manager, November, v. 3, no. 8, p. 56.

The Role of Federal and State Geological Surveys in Aggregate Studies: Aggregates

Manager, December, v. 3, no. 9, p. 56. 
Langer, W.H., 1999, Global Perspectives: Aggregates Manager.

This is a series of 12 single-page articles listed below describing the international aspects of the use of natural aggregate (crushed stone and sand and gravel). 62 .

, Aggregate Role in the Growth of Cities: Aggregates Manager, February, v. 3, no. 11, p. 60.

Reclamation - a New Art Form: Aggregates Manager, March, v. 3, no. 12, p. 64.

, Death, Taxes, and Environmental Problems: Aggregates Manager, April, v. 4, no. 1, p. 50 .

The Hole Story: Aggregates Manager, May, v. 4, no. 2, p. 60.

(Un)Natural Habitat: Aggregates Manager, June, v. 4, no. 3, p. 58.

, The Best Laid Plans: Aggregates Manager, July, v. 4, no. 4, p. 56.

, Aggregate Operations Uncover the Earth's Secrets: Aggregates Manager, August, v. 4, no. 5 , p. 62 .

, All Earthwork Activities require Extreme Caution: Aggregates Manager, September, v. 4 , no. 6, p. 60.

, Quarries and Pits - Places of Higher Learning: Aggregates Manager, October, v. 4, no. 7, p. 60 .

, Sustainability, Biodiversity, and ISO 14000: Aggregates Manager, November, v. 4, no. 8, p. 58.

, History Shows that Every Age is a Stone Age: Aggregates Manager, December, v. 4, no. 9, p. 58.

Langer, W.H., 1999, Aggregate - A Global Perspective, Quarry - Australia, Malaysia, New Zealand.

Each of the twelve articles that appeared in Aggregates Manager, one each month for the year 1999, was simultaneously published in Quarry. Each article is 1 page long and describes the international aspects of the use of natural aggregate (crushed stone and sand and gravel).

Langer, W.H., 1999, Aggregate availability - What you see is not necessarily what you get: International Center for Aggregates Research, Austin, Texas, 1999, 10p.

The cost and difficulty of identifying, permitting, and mining new sources of natural aggregate continues to increase. A number of factors may limit reserves. The reserves may be located in a geologic area where aggregate extraction will result in significant environmental impacts. The reserves may not meet the strict quality requirements for current or future use. The reserves may not be accessible because of conflicting land use, citizen opposition, or zoning and regulations. Geologic characterization of potential resources can help reduce the risk of unexpectedly losing reserves to unforeseen causes.

Langer, W.H., 2000, Carved in stone: Aggregates Manager.

This is a series of 12 single-page articles listed below describing the relationships between geology and natural aggregate (crushed stone and sand and gravel).

Geology: Aggregates Manager, January, v. 4, no. 10, p. 66.

, Limestone - Nature's Geologic Wonder: Aggregates Manager, February, v. 4, no. 11, p. 62.

, Valuation of Aggregate Reserves - The Geologist's Role: Aggregates Manager, March, v. 4 , no. 12 , p. 60 .

A Test of Strength: Aggregates Manager, April, v. 5, no. 1, p. 58.

(Mis) Taken for Granite: Aggregates Manager, May, v. 5, no. 2, p. 60.

, Get with the System: Aggregates Manager, June, v. 5, no. 3, p. 58.

Avoiding the Trap Rock Trap: Aggregates Manager, July, v. 5, no. 4, p. 64.

The Stories in a Map: Aggregates Manager, August, v. 5, no. 5, p. 58. 
, Miscellaneous Rocks - The Good, the Bad, and the Ugly: Aggregates Manager,

September, v. 5, no. 6, p. 58.

, A Geologist's-eye View of the Landscape: Aggregates Manager, October, v. 5, no. 7, p. 62.

, Aridos - ¿Porque? (Why Aggregate?) : Aggregates Manager, November, v. 5, no. 8, p. 50.

, Geologists are from Venus, Engineers are from Mars: Aggregates Manager, Devember, v. 5 , no. 9 , p. 50.

Langer, W.H., 2000, Carved in stone: Quarry - Australia, Malaysia, New Zealand.

Each of the twelve articles that appeared in Aggregates Manager above, one each month for the year 2000, was simultaneously published in Quarry. Each article is 1 page long and describes the relationships between geology and natural aggregate (crushed stone and sand and gravel).

Langer, W.H., 2001, Geology, Aggregates and the Environment: Aggregates Manager.

This is a series of articles that appeared in Aggregates Manager, one each month, for the year 2001. Each article is 1 page long and describes relationships between geology, aggregate (crushed stone and sand and gravel), and the environment.

, Nature, to Be Commanded, Must Be Obeyed: Aggregates Manager, January, v. 5, no. 10, p. 50.

, A Point of View: Aggregates Manager, February, v. 5, no. 11, p. 9.

, Thinking Like a River: Aggregates Manager, March, v. 5, no. 12, p. 54.

Act Like a River: Aggregates Manager, April, v. 6, no. 1, p. 56.

, Karst - An invaluable but challenging source of aggregate: Aggregates Manager, May, v. 6 , no. 2 , p. 58 .

Sinkhole - (n) a depression formed in karst by collapse of the land surface: Aggregates

Manager, June, v. 6, no. 3, p. 58.

, Planning Limestone Extraction in Karst: Aggregates Manager, July, v. 6, no. 4, p. 50.

Langer, W.H., 2001, Natural Capital: Quarry - Australia, Malaysia, New Zealand.

Each of the articles that appeared in Aggregates Manager above, one each month for the year 2000, was simultaneously published in Quarry. Each article is 1 page long and describes the relationships between geology, aggregate (crushed stone and sand and gravel), and the environment.

Langer, W.H., 2001, Geological considerations affecting aggregate specifications, in Proceedings, $9^{\text {th }}$ Annual Symposium, International Center for Aggregates Research: International Center for Aggregates Research, Austin, Texas, 16 p.

The development and application of testing procedures to assess the properties of aggregate resources have been studied for most of the $20^{\text {th }}$ Century. Ever so, the resulting testing procedures do not always ensure that the aggregate will perform well in service. The influence of geologic factors on rock properties and their suitability for use as aggregate has been recognized, but geologic factors have not received the same emphasis in the literature as engineering aspects. This paper describes the geologic factors that affect rock properties, and encourages the broader use of geology in the development of empirical tests, establishment of specification limits based upon such tests, and interpretation of the results of those tests for selection of aggregates for use under specific conditions of service.

Langer, W.H., 2001, Environmental impacts of mining natural aggregate, in Bon, R.L., Riordan, R.F., Tripp, B.T, and Krukowski, S.T., eds., Proceedings of the $35^{\text {th }}$ Forum on Geology of Industrial Minerals - The Intermountain West Forum, Salt Lake City, Utah: Utah Geological Survey Miscellaneous Publication 01-2, p. 127-138. 
Most environmental impacts associated with aggregate mining are benign. Extracting aggregate seldom produces acid mine drainage or other toxic effects commonly associated with mining of metallic or energy resources. The most obvious environmental impact of aggregate mining is the conversion of land use, most likely from undeveloped or agricultural land use, to a hole in the ground. This major impact is accompanied by loss of habitat, noise, dust, blasting effects, erosion, sedimentation, and changes to the visual scene. Some of the impacts are short-lived, and most are easy to predict and easy to observe. Most impacts can be controlled, mitigated, or kept at tolerable levels and can be restricted to the immediate vicinity of the aggregate operation by employing responsible operational practices that use available technology. Mining aggregate can lead to serious environmental impacts in some situations. Some geologic environments such as active stream channels, slide-prone areas, and karst terrain are dynamic and respond rapidly to outside stimuli including aggregate mining. Some geomorphic areas and (or) ecosystems underlain with aggregate serve as habitat for rare or endangered species. Similarly, some geomorphic features are themselves rare examples of geologic phenomena or processes. Mining aggregate might be acceptable in some of these areas, but should be conducted only after careful consideration, and then only with extreme prudence. Failure to do so can lead to serious, long-lasting, and irreversible environmental consequences, either in the vicinity of the site or at locations distant from the site. Environmental impacts caused by irresponsible aggregate mining can compromise mining in an entire region.

Langer, W.H., in press, Aggregate resources of the United States - An overview, in Scott, P.W., and Bristow, C.M., eds., Industrial Minerals and Extractive Industry Geology, Proceedings of the 36th Forum on the Geology of Industrial Minerals and $11^{\text {th }}$ Extractive Industry Geology Conference, Bath, England, 2000: Bath, England, Geological Society Publishing House.

In 1999 the U.S. produced about 2.64 billion tonnes of aggregate worth about $\$ 13.7$ billion. Both crushed stone and sand and gravel are produced in virtually every State, although limited quantities are available in the Gulf Coastal Plain, the Colorado Plateau, the Wyoming Basin and the Great Plains. Prices vary depending on the product and location. Most aggregates are transported by road, and minor amounts by railroad, barge on navigable inland channels, and through the Great Lake ports. Imports and exports of aggregates are very minor. A major amount of crushed stone aggregates is consumed by public projects, mostly for highway and road construction and maintenance. A significant amount of sand and gravel is used for concrete aggregate. Recycled aggregates account for about $8 \%$ of total demand, although the amount recycled is thought to be increasing. Current issues facing the industry include the differences in quality specifications between States, adjusting to the increasing concern for the impact of aggregate mining on the environment, health issues from particulate matter and crystalline silica, and the complexity of obtaining permits for extraction. Reduction in the number of companies extracting aggregates is likely to occur through acquisitions.

Langer, W.H., 2001, Environmental risk analysis and aggregate mining, in 37th Forum on the Geology of Industrial Minerals, Victoria, British Columbia, 2001, Program and Extended Abstracts: Victoria, British Columbia, British Columbia Ministry of Energy and Petroleum, p. 55 .

Environmental risk analysis uses a systematic approach to identify potential environmental impacts and hazards, the consequences of those impacts or hazards, and the likelihood of those impacts or hazards becoming an event. The environmental risks are evaluated and opportunities for risk reduction are identified. Risks exist because there are uncertainties. The uncertainty of ignorance occurs because the hazards and risks have not been investigated. The uncertainty of unknown occurs because of the limits to our knowledge. The uncertainty of disagreement exists when experts cannot agree or when experts and the thoughtful laypersons do not agree because of lack of data, misconceptions, and mistrust. The uncertainty of linguistics exists because we often refer to events or quantities in imprecise terms, or in specialized jargon familiar only to people in our profession. The uncertainty of performance occurs because people make mistakes. The uncertainty of unpredictability occurs because some things, such as weather and earthquakes, are inherently unpredictable, and because the natural are in a constant state of change. Some of the potential environmental impacts associated with aggregate mining, such as noise, can be measured and expressed in quantitative terms such as the amount of time the noise exceeds the background level by a specified amount. Other potential environmental impacts, such as sinkhole collapse due to quarry dewatering, are the result of a series of cascading impacts. These impacts are difficult to measure quantitatively and, therefore, commonly are expressed in qualitative terms. One way to qualitatively assess environmental impacts is to characterize their nature in terms such as the range of the impact, the timing of the impact, the duration of the impact, the magnitude of the impact, the ability to predict the impact, and the ability to control the impact. 
Langer, W.H., Green, G.N., Knepper, D.H., Jr., Lindsey, D.A., Moore, D.W., Nealey, L.D., and Reed, J.C., 1997, Distribution and quality of potential sources of aggregate, Infrastructure Resources Project Area, Colorado and Wyoming: U.S. Geological Survey Open-File Report 97-477 (CDROM). Available at URL http://greenwood.cr.usgs.gov/pub/open-filereports/ofr-97-0477/

This map was prepared by attributing the Digital Geologic Map of Colorado - USGS Open File Report 92-0507 with parameters reflecting the quality of unconsolidated materials and bedrock for use as aggregate (sand and gravel or crushed stone). Potential sources of aggregate are defined according to general physical and chemical quality. Physical quality is defined as satisfactory, fair, or poor. Chemical quality is defined as either innocuous or deleterious.

Langer, W.H., and Knepper, D.H., Jr., 1998, Geologic characterization of natural aggregate - A geologist's guide to natural aggregate resource assessment, in Bobrowsky, P.T., ed., Aggregate Resources - A Global Perspective: A.A. Balkema Publishers, Rotterdam, Netherlands, p. 275-293.

This report is intended to help the field geologist determine the aggregate potential of an area. For purposes of this report aggregate is defined as crushed stone, and sand and gravel. The report bridges the gap between the geologist and the aggregate specialist by acquainting the geologist with some of the technical aspects of the aggregate industry. This report also provides the geologist with suggested field observations that will aid in identifying relationships between the geologic properties of rocks and sand and gravel and their likely performance as an aggregate

Langer, W.H., and Lindsey, D.A., 1999, Preliminary deposit models for sand and gravel in the Cache la Poudre River valley: U.S. Geological Survey Open-File Report 99-587, 27 p. Available at URL http:/greenwood.cr.usgs.gov/pub/open-file-reports/ofr-99-0587/

Four different gravel deposit models are defined for the Cache la Poudre River valley. From the highest (oldest) to lowest (youngest) the models are dissected terraces, alluvial fans, high terraces, and floodplains and low terraces. The floodplain and low terraces are underlain by coarse gravel and sand, which currently is the most exploited aggregate resource in the Cache la Poudre River valley. From top to bottom, the floodplain and low terraces are underlain by 3 5 feet of soil and overbank deposits, and two well sorted, stratified, sand and gravel deposits. A third stratigraphic unit described as "dirty gravel" locally occurs in the study area, and consists of very indurated cobble/pebble gravel with a silt matrix.

Langer, W.H., Lindsey, D.A., and Knepper, D.H., Jr., 1999, Aggregate maps of the Front Range Infrastructure Resources Project area, in Proceedings of the U.S. Geological Survey Front Range Infrastructure Resources Project Stakeholder's Meeting, 4 November 1998: U.S. Geological Survey Open-File Report 99-001, p. 23-24.

This abstract describes research to add natural aggregate attributes to the digital geologic maps of Colorado and Wyoming and the use of these data to prepare a regional natural aggregate potential map of the Colorado Front Range urban corridor.

Langer, W.H., Lindsey, D.A., and Knepper, D.H., Jr., 1999, A GIS and decision support system demonstration of aggregate maps and data for the Front Range Infrastructure Resources Project area, in Johnson, K.S., ed., Proceedings, $34^{\text {th }}$ Forum on the Geology of Industrial Minerals, 2-6 May 1998, Norman, Oklahoma: Oklahoma Geological Survey Circular 102, p. 139-146.

The Denver, Colorado area is experiencing difficulties in obtaining adequate supplies of suitable sources of natural aggregate. Geographic information systems (GIS) and decision support systems (DSS) are valuable tools for nontechnical users, not only to manage and analyze data, but also to display and visualize data. GIS such as ArcView can display maps showing the distribution and quality of aggregate resources. It can relate those data to other spatial information such as rivers and highways. Equally important, it can relate those date to information in the form of 
photographs, drawings, illustrations, tables, and charts. All of this information can help explain the three-dimensional variability of resources such as aggregate. DSS such as Smart Places can help manage the technical data relating to aggregate or other resources. Smart Places can query various map layers or databases. It can then use information obtained from those map layers in mathematical equations supplied by program developers to predict outcomes of various land-use scenarios.

Langer, W.H., Arbogast, B.F., Ellefsen, K.F., Fitterman, D.V., Knepper, D.H. Jr., Lindsey, D.A., Livo, K.E., Roelle, J.E., and Wilburn, D.R., 2000, Techniques, products, and progress on the U.S. Geological Survey Infrastructure Resources Project: Proceedings, 8th Annual Symposium, International Center for Aggregates Research, University of Austin, Texas (CD ROM).

The U.S. Geological Survey initiated the Front Range Infrastructure Resources Project in October 1995, to collect, compile, and analyze new and existing data on aggregate, water, and energy resources along the Colorado Front Range. Data collection and methods development primarily were restricted to a demonstration area consisting of the Denver metropolitan area and the rapidly growing areas to the north. Project results to date on aggregate resources include digital aggregate resource maps; developing aggregate deposit resource models, formulation of field tools, geophysical and remote sensing techniques, computer processing and display of data including geographic information systems and decision support systems; and investigating human related aspects such as sterilization, supply and demand, and mined-land reclamation.

Langer, William H., and Ellefsen, K.J., 2001, Natural aggregate - Geophysical opportunities, in Symposium on the Application of Geophysics to Engineering and Environmental Problems (SAGEEP), Denver, Colo., 2001, Proceedings: Denver, Colo., Omnipress, CD-ROM, various pagination.

Geophysicists have the opportunity to provide critical information concerning the identification, characterization, and extraction of suitable aggregate, and concerning protection of the environment from adverse impacts of aggregate extraction. Geophysical surveys of aggregate deposits also provide opportunities for conducting traditional research on geophysical methods. Research is needed on techniques to efficiently acquire and process ground-based geophysical data, airborne geophysical data, and remotely sensed data. Such data are needed to detect and delineate potential sources of crushed stone and deposits of sand and gravel. Better techniques are also needed to determine deposit thickness, characterize variations within a deposit, characterize physical properties of aggregate resources, characterize mine sites, and characterize areas of potential environmental impacts.

Langer, W.H., and Kolm, K.E., 2001, A systems approach to conceptualization, characterization, and evaluation of environmental impacts from aggregate mining, in Kuula-Väisänen, Pirjo, and Uusinkoa, Raimo, eds., Proceedings, Aggregate 2001 - Environment and Economy, Helsinki, Finland, August 6-10, 2001: Tampere University of Technology, Laboratory of Engineering Geology, Publication No. 51, v. 2, p. 401-406.

Environmental impact characterization and evaluation is an iterative, step-wise process that develops multiple working hypotheses for possible environmental responses to aggregate extraction. The process starts with the development of a preliminary understanding of the environmental system based on the general geologic and hydrologic setting, and is followed by data collection and analysis, and subsequent refinement of that understanding. The parameters of the various systems are modified to reflect anticipated conditions as they might occur under different mining scenarios. The conditions under the pre-mining scenario are compared with the conditions under the post-mining scenario to identify potential environmental impacts for each method of mining. Finally, potential impacts are evaluated to determine the relative level of impacts from each scenario. 
Langer, W.H., and Kolm, K.E., 2001, Hierarchical Systems Analysis of Potential Environmental Impacts from Aggregate Mining Activities: Preprint no. 01-103, SME Annual Meeting, Denver, Colorado, 2001, Society for Mining, Metallurgy, and Exploration, Inc., Littleton, Colorado, p. 1-7.

Developing natural aggregate resources (sand, gravel, and stone) creates environmental impacts. A systems analysis method has been designed to characterize the components of the environmental system, identify potential impacts to those systems, and evaluate the extent of those impacts. The step-wise method consists of problem definition, data collection, preliminary conceptualization and characterization, additional data collection, data analysis, and refinement. The method requires analyzes of various systems making up the environment, including land surface, geomorphic, subsurface, and groundwater systems. After system characterization is complete, the method focuses on identifying and evaluating potential environmental impacts to determine acceptable mining strategies.

Lindsey, D.A., 1997, Introduction to sand and gravel deposit models, Front Range, Colorado: U.S. Geological Survey Open-File Report 97-81. Available at URL http://greenwood.cr.usgs.gov/pub/open-file-reports/ofr-97-0081/

This preliminary report introduces concepts and data types useful for developing descriptive deposit models of gravel deposits in the Front Range Urban Corridor, Colorado.

Lindsey, D.A., and Langer, W.H., 1998, Slide show on gravel deposit models and measuring aggregate quality, Front Range Urban Corridor, Colorado: U.S. Geological Survey Open File Report 98-332 (17 slides). Available at URL http://greenwood.cr.usgs.gov/pub/openfile-reports/ofr-98-0332/

This Powerpoint slide show summarizes a presentation at the $34^{\text {th }}$ Forum on the Geology of Industrial Minerals, 26 May 1998, Norman, Oklahoma. The slide show covers classification and definition of models for the major sources of sand and gravel in the Front Range Urban Corridor, useful measures of aggregate quality among the deposits, and guidelines for the appropriate scale for sampling aggregate quality.

Lindsey, D.A., and Langer, W.H., 1999, Defining models and measuring aggregate quality for gravel deposits of the Front Range Urban Corridor, Colorado, in Johnson, K.S., ed., Proceedings, $34^{\text {th }}$ Forum on the Geology of Industrial Minerals, 2-6 May 1998, Norman, Oklahoma: Oklahoma Geological Survey Circular 102, p. 125-137.

This report classifies and defines models for the major sources of sand and gravel in the Front Range Urban Corridor, identifies useful measures of aggregate quality among the deposits, and offers guidelines for the appropriate scale for sampling aggregate quality.

Lindsey, D.A., and Langer, W.H., 1999, Gravel deposits of the South Platte River Valley north of Denver, Colorado, in Proceedings of the U.S. Geological Survey Front Range Infrastructure Resources Project Stakeholder's Meeting, 4 November 1998: U.S. Geological Survey Open-File Report 99-001, p. 25-28.

This report describes the physiographic setting, stratigraphy, and some field measures of aggregate quality for gravel deposits in the South Platte River valley north of Denver, Colo.

Lindsey, D.A., and Shary, J.F., 1997, Field measures of gravel in the South Platte River north of Denver, Colorado - A pilot study: USGS Open-File Report 97-451, 19p. Available at URL http://greenwood.cr.usgs.gov/pub/open-file-reports/ofr-97-0451/

This report examines sampling methods and design for field measures of aggregate quality in modern gravels of the South Platte River north of Denver, Colorado. 
Lindsey, D.A., Langer, W.H, Cummings, L.S., and Shary, J.F., 1998, Gravel deposits of the South Platte river valley north of Denver, Colorado, Part A - Stratigraphy and sedimentary structures: USGS Open-File Report 98-148-A, 18p. Available at URL http://greenwood.cr.usgs.gov/pub/open-file-reports/ofr-98-0148/

Part A describes the stratigraphy and sedimentary structures of gravel deposits in the South Platte River valley, with emphasis on producing gravels beneath the floodplain and low terraces. Stratigraphy and history of gravel deposition is interpreted with the aid of new information on the age of the gravel deposits. The report is in Portable Document Format (PDF) and requires Adobe Acrobat ReaderTM (v. 3.0 or later) for viewing and printing.

Lindsey, D.A., Langer, W.H., and Shary, J.F., 1998, Gravel deposits of the South Platte river valley north of Denver, Colorado, Part B - Quality of gravel deposits for aggregate: USGS Open-File Report 98-148-B, 24p. Available at URL http://greenwood.cr.usgs.gov/pub/openfile-reports/ofr-98-0148/

Part B describes the quality of gravel deposits in terms of particle size, lithology, shape and roundness. Stratigraphic and regional variation is statistically analyzed, and lithologic control of some characteristics is evaluated. Laboratory tests were conducted on gravel and individual lithologies within gravel to measure resistance to abrasion. The report is in Portable Document Format (PDF) and requires Adobe Acrobat ReaderTM (v. 3.0 or later) for viewing and printing.

Lindsey, D.A., Taggert, J.E., and Meeker, G.P., 1998, Gravel deposits of the South Platte river valley north of Denver, Colorado, Part C - Description, composition, and origin of clay lenses in gravel: USGS Open-File Report 98-148-C, 7p. Available at URL http://greenwood.cr.usgs.gov/pub/open-file-reports/ofr-98-0148/

Part $\mathrm{C}$ describes the physical character and composition of clay lenses in gravel. Possible explanations for the origin of clay lenses are proposed, and implications for prediction of their extent in the subsurface are summarized. The report is in Portable Document Format (PDF) and requires Adobe Acrobat ReaderTM (v. 3.0 or later) for viewing and printing.

Livo, K.E., and Knepper, D.H., Jr., 1999, Industrial-mineral characterization using remotely sensed data, in Proceedings of the U.S. Geological Survey Front Range Infrastructure Resources Project Stakeholder's Meeting, 4 November 1998: U.S. Geological Survey OpenFile Report 99-001, p. 29-30.

This abstract accompanied a poster describing the application of NASA AVIRIS data to map vegetation and the mineralogy of exposed soils, sediments, and rocks and the potential applications of the mapping in the Front Range urban corridor.

Livo, K.E., and Knepper, D.H., Jr., 1999, Processing remotely sensed data for industrial mineral prospecting, in Johnson, K.S., ed., Proceedings, $34^{\text {th }}$ Forum on the Geology of Industrial Minerals, 2-6 May 1998, Norman, Oklahoma: Oklahoma Geological Survey Circular 102, p. 151-152.

This abstract accompanied a poster describing the characteristics of Landsat Thematic Mapper (TM) and Advanced Visible and Infrared Imaging System (AVIRIS) remote sensing data and their potential applications in the assessment of potential sand and gravel and crushed stone aggregate sources.

Matos, G., and Wagner, L., 1998, Consumption of Materials in the United States, 1900 to 1995: Annual Review of Energy and the Environment, 1998, Volume 23, p. 107-122.

The USGS examined the general historical shifts in the consumption of materials and the significance of trends in materials consumption. This paper is based on information collected over the course of the 20th century for the United States and the world, and places U.S. consumption in its perspective with the global community. During this century, not only have the types of materials utilized by mankind changed, but also the quantity consumed in the 
United States has grown dramatically.

Melick, Roger, Furman, T.L., Langer, W.H., and Van Brenk, H., 1998, Using geographic information systems with specific examples for the aggregate industry: U.S. Geological Survey Open-File Report 98-39. Available at URL http://greenwood.cr.usgs.gov/pub/openfile-reports/ofr-97-0451/

This online publication demonstrates the use of Geographic Information Systems (GIS) in the aggregate industry. It is a cooperative effort between the USGS and representatives from the aggregate industry.

Schwochow, S.D., Shroba, R.R., and Wicklein, P.C., 1974, Atlas of sand, gravel, and quarry aggregate resources, Colorado Front Range Counties: Colorado Geological Survey Special Publication 5B, digitized and compiled by Cappa, J.A., Hiatt, C.S., Litke, D.W., McCormick, M.L., and Sadlick, Joseph, 2000, Colorado Geological Survey and U.S. Geological Survey Open-File Report 00-9 (CD-ROM).

The digital dataset on this CD-ROM is a representation of the Colorado Geological Survey's Special Publication 5A/5B entitled, "Sand, Gravel, and Quarry Aggregate Resources, Colorado Front Range Counties" by Schwochow, Shroba, and Wicklein, published in 1974.

U.S. Geological Survey, 1998, Materials Flow and Sustainability: U.S. Geological Survey Fact Sheet FS 068-98, June 1998. Available at URL http://greenwood.cr.usgs.gov/pub/factsheets/fs-0068-98/

Materials extracted from the Earth are necessary to produce our most fundamental needs - food, clothing, and shelter. Materials are needed to maintain and improve our standard of living. Understanding the whole system of materials flow, from source to ultimate disposition, can help us better manage the use of natural resources and protect the environment.

Wilburn, D.R., and Goonan, T.G., 1998, Aggregates from Natural and Recycled Sources: Economic Assessments for Construction Applications--A Materials Flow Analysis: U.S. Geological Survey Circular 1176, 37p. Available at URL http://greenwood.cr.usgs.gov/pub/circulars/c1176/

Increased amounts of recycled materials are being used to supplement natural aggregates (derived from crushed stone, sand and gravel) in road construction. An understanding of the economics and factors affecting the level of aggregates recycling is useful in estimating the potential for recycling and in assessing the total supply picture of aggregates. This investigation includes a descriptive analysis of the supply sources, technology, costs, incentives, deterrents, and market relationships associated with the production of aggregates.

Wilburn, D.R., and Langer, W.H., 2000, Aggregate resources in the new millennium - An aggregate use and permitting study along the Colorado Front Range: U.S. Geological Survey Open File Report 00-258, 22 p. Available at URL http://greenwood.cr.usgs.gov/pub/openfile-reports/ofr-00-0258/

\footnotetext{
The study indicates that the amount of aggregates being permitted has steadily decreased over time. The Denver metropolitan area has been producing more aggregates than it is permitting since 1991, and the Fort Collins-Greeley area is currently permitting about what it is producing. If this trend continues, aggregate operators may be forced to move to resource areas even farther away from local markets, resulting in even higher transportation costs. Increased costs for these aggregates would be passed along to the State or counties as higher construction bids, to the contractor as higher supply costs, and ultimately to the consumer in the form of higher taxes or user fees.
} 


\title{
Energy Resources
}

Cook T., 1998, A computer model to determine the most likely areas for future drilling in the "D" and Muddy ("J") Sandstones, in Proceedings of the U.S. Geological Survey Front Range Infrastructure Resources Project Stakeholder's Meeting, Nov. 4, 1998: U.S. Geological Survey Open-File Report 99-0001, p. 5-6.

\begin{abstract}
This report presents preliminary results of computer modeling as it bears on identifying areas of potential future oil and gas exploration and production, principally in the Cretaceous "D" and "J" Sandstones in the greater Wattenberg area, Denver Basin, Front Range of Colorado.
\end{abstract}

Fishman, N.S., 1998, Front Range Infrastructure Resources Project-Energy resources activities: U.S. Geological Survey Fact Sheet 109-98. Available at URL http:/greenwood.cr.usgs.gov/pub/fact-sheets/fs-0109-98/

This report provides a brief overview of the scientific activities being pursued through funding from the Energy Resources Program of the USGS in the Front Range Infrastructure Resources Project.

Fishman, N.S., Woodward, C.L., and Langer, W.H., 1998, Influence of the oil and gas production infrastructure on land use in the Front Range of Colorado, in Proceedings of the U.S. Geological Survey Front Range Infrastructure Resources Project Stakeholder's Meeting, Nov. 4, 1998: U.S. Geological Survey Open-File Report 99-0001, p. 10-13.

\footnotetext{
This report presents preliminary findings of studies designed to determine the impact of the oil and gas production infrastructure on other land uses, including the availability of aggregate resources, in the Front Range of Colorado. Over 3 square miles of land is consumed by the energy production infrastucture, and much aggregate resource occurs near areas of energy production, which could prevent future exploitation of the aggregate.
}

Fishman, N.S., Deszcz-Pan, M, Kucks, R.P., Roberts, S.B., Higley, D.K., Woodward, C.L., Otton, J.K., and Cook, T., 2001, Detection of oil, natural gas, and coal production infrastructure by magnetic surveys, Front Range of Colorado, in Symposium on the Application of Geophysics to Engineering and Environmental Problems (SAGEEP), Denver, Colo., 2001, Proceedings: Denver, Colo., Omnipress, CD-ROM, various pagination.

\footnotetext{
Detection of oil and gas wells, as well as clinker associated with coal mine fires was shown to be possible using data collected from aeromagnetic surveys flown at low elevations. The utility of magnetic data used in this way is significant, especially when searching for hidden wells or areas of past and current coal mine fires.
}

Fishman, N.S. and Roberts, S.B., 2001, Energy resources and changing land use, Front Range of Colorado-AAPG Field Trip Guide, in association with the 2001 AAPG-EMD Annual Meeting: U.S. Geological Survey Open File Report 01-172, 57 p.

\footnotetext{
Rapid urbanization in the Front Range of Colorado is overriding areas of past, present and future energy production. This paper was designed to provide field trip participants with information about how energy production and urbanization are competing for some of the same land, and how future land use conflicts may increase due to these competing needs.
}

Higley, D.K., and Cox, D. O., 1998, Oil and natural Gas Resources of the Wattenberg Field, Denver Basin, Colorado, in Proceedings of the U.S. Geological Survey Front Range Infrastructure Resources Project Stakeholder's Meeting, Nov. 4, 1998: U.S. Geological Survey Open-File Report 99-0001, p. 19-22.

This report presents information concerning oil and gas resources in the Wattenberg Field, Front Range of Colorado. An important factor in understanding the distribution of oil and gas in the field is recognition of large wrench faults that cut across the region, which may either enhance or diminish potential for production. 
Higley, D.K., and Cox, D.O., 1998, Influence of zones of crustal weakness on 3-D distribution of gas across the Wattenberg field, Denver Basin, Colorado, in Second Annual Innovative Applications of Petroleum Technology Rocky Mountain Association of Geologists and Gas Research Institute Fall Symposia, Abstract with Program, 7 p.

This report presents information concerning oil and gas resources in the Wattenberg Field, Front Range of Colorado. An important factor in understanding the distribution of oil and gas in the field is recognition of large wrench faults that cut across the region, which may either enhance or diminish potential for production.

Higley, D.K., Pollastro, R.M., and Clayton, J.L., 1995, Denver Basin Province (039) in Gautier, D.L., Dolton, G.L., Takahashi, K.I., and Varnes, K.L., eds., 1995 National assessment of United States oil and gas resources on CD-ROM: U.S. Geological Survey Digital Data Series 30. Available at URL http://greenwood.cr.usgs.gov/pub/dds/dds-030/

Data files of the oil and gas assessment are available in self-extracting archives for Windows (1.8 MB) or Macintosh (3.1 MB) Each version includes text of the Executive Summary in MS Word format, JPEG images of maps and figures, and JPEG image viewing software. Note: the JPEG image viewing software included with each package are shareware programs from non-U.S. Government sources.

Higley, D.K., Quinn, J., and Bergamaschi, A, 1997, 3-D Distribution of gas production across the Wattenberg field, Denver Basin, Colorado; 1997 Rocky Mountain Section Meeting, American Association of Petroleum Geologists Bulletin, v. 81, p. 1225.

This abstract outlines in three dimensions, the distribution of gas in the "J" Sandstone produced in the Wattenberg field, in the Front Range of Colorado.

Otton J.K, and Zielinski, R.A., 1998, Chemical criteria for determining the origin and dispersion of highly soluble salts in soils and waters near an oilfield operation, Logan County, Colorado, in Proceedings of the Fifth International Petroleum Environmental Conference-Environmental issues and solutions in petroleum exploration, production and refining: South Central Environmental Resources Alliance, University of Tulsa, p. 953-973.

Soluble salts derived from waters produced along with oil have been found in soils and shallow ground water below a produced water holding pit. The salts are high in chloride, bicarbonate, and sulfate, all of which point to the probable source being oilfield-produced waters. Geochemical studies such as these can help to not only determine the presence of salts in soils but also assist in determining their source.

Otton, J.K., and Zielinski, R.A., 1998, Characteristics and origins of saline (alkalai) soils in the Front Range portion of the Denver Basin, in Proceedings of the U.S. Geological Survey Front Range Infrastructure Resources Project Stakeholder's Meeting, Nov. 4, 1998: U.S. Geological Survey Open-File Report 99-0001, p. 31-34.

Saline soils are common in the Front Range of Colorado, and their origin is the focus of this paper. Although waters produced along with oil and gas was considered a possible source of the saline soils, instead, natural processes are considered responsible for the salt formation.

Roberts, S.B., and Fishman, N.S., 2000, Coal-bed methane potential in the Laramie Formation, greater Wattenberg area, Denver Basin, Colorado-just wishful thinking? American Association of Petroleum Geologists Bulletin, v. 84, p. 1245.

The coal-bed methane potential of the Cretaceous Laramie Formation in the Denver Basin, Colorado, was considered because of the interest that exists across the country in coal beds as a target for natural gas production. Although existing data related to coal-bed methane in the Laramie Formation are sparse, accounts of gas in mines that produced Laramie Formation coal as well as the occurrence of methane in water wells penetrating coal beds suggests the Laramie may indeed be a potential economically viable reservoir for natural gas. 
Roberts, S.B., Hynes, J.L., and Woodward, C.L., 1998, Digital coverages showing the extent of mining, bedrock faults, and thickness of overburden above abandoned coal mines in the Boulder-Weld Coal Field, Boulder and Weld Counties, Colorado: A cooperative effort between the U.S. Geological Survey and the Colorado Geological Survey, in Proceedings of the U.S. Geological Survey Front Range Infrastructure Resources Project Stakeholder's Meeting, Nov. 4, 1998: U.S. Geological Survey Open-File Report 99-0001, p. 35-37.

Preliminary versions of digital maps showing extent of mining and depth to mining exist for the Boulder-Weld Coal Field, were produced from old paper copies, and the data were also revised with new information concerning the extent of mining.

Roberts, S.B., Hynes, J.L., and Woodward, C.L., 2000, Maps showing extent of mining, mine shaft and adit locations, airshafts, bedrock faults, and thickness of overburden above abandoned coal mining in the Boulder-Weld coal field: U.S. Geological Survey Geologic Investigations I-2735, 1:48,000, 1 sheet. Available at URL http:/greenwood.cr.usgs.gov/pub/i-maps/i-2735/

\footnotetext{
The explosive urban and commercial growth in the past few years in Boulder and Weld counties, Colorado has been, in some areas, over abandoned coal mines of the Boulder-Weld Coal Field. Mines of the coal field were developed at depths ranging from $<50$ feet to $>500$ feet beneath the land surface. This map will benefit planners and developers alike because it brings together various pieces of information about old abandoned coal mines so that users can conveniently consider a variety of information concerning past mining as part of future planning.
}

Zielinski, R.A., Otton, J.K., and Johnson, C.A., 2001, Sources of salinity near a coal mine spoil pile, North-central Colorado: Journal of Environmental Quality, v. 30.

\footnotetext{
Sampling along a stream and analysis of soil leachates indicate that the major sources of salinity and trace elements to the drainage are local irrigated fields and shallow ground water that drains from the fields. A spoil pile from an old abandoned coal mine contributes only minor amounts of dissolved species to the surface waters.
}

\section{Water Resources}

Arnold, L.R., and Robson, S.G., 2001, Mapping of bedrock aquifers in the Denver Basin using borehole geophysical logs, in Symposium on the Application of Geophysics to Engineering and Environmental Problems, Denver, Colorado, March 4-7, 2001, Proceedings: Denver, Colorado, Environmental and Engineering Geophysical Society, Published on CD-ROM, 12 p.

This report presents methods and results of mapping bedrock aquifers in the Denver Basin using borehole geophysical logs.

Heiny, J.S., 1999, Ground-water resources as part of the Front Range Infrastructure Resources Project (FRIRP) [abs.]: American Water Resources Association-Colorado Section, Annual Symposium, Golden, Colorado, March 19, 1999, 1 p.

This abstract was written for a presentation of the Front Range Infrastructure Resources Project at the 1999 Annual Symposium of the American Water Resources Association-Colorado Section.

Robson, S.G., 1996, Geohydrology of the shallow aquifers in the Denver metropolitan area, Colorado: U.S. Geological Survey Hydrologic Investigations Atlas HA-736, 5 sheets, scale 1:50,000. Available at URL http://webserver.cr.usgs.gov/frirp/water_project/shaqpage.html 
This report presents the results of a systematic mapping of the extent, thickness, and water-table altitude of the shallow aquifers in a 700-square-mile part of the greater Denver metropolitan area in Colorado. The report consists of 5 map sheets that show (1) the thickness and extent of the unconsolidated sediments that overlie bedrock formations in the area, (2) the altitude and configuration of the buried bedrock surface, (3) the altitude of the water table and direction of ground-water movement, (4) the saturated thickness of the shallow aquifers, and (5) the depth to the water table in the shallow aquifers.

Robson, S.G., 2001, Status of shallow-aquifer mapping in the northern Front Range area, Colorado: U.S. Geological Survey Fact Sheet 069-00, 2 p.

This fact sheet summarizes water-resources work that was completed as part of the Front Range Infrastructure Resources Project.

Robson, S.G., Van Slyke, George, and Graham, Glenn, 1998, Structure, outcrop, and subcrop of the bedrock aquifers along the western margin of the Denver Basin, Colorado. U.S. Geological Survey Hydrologic Investigations Atlas HA-742, 5 sheets, scale 1:50,000. [Prepared in cooperation with the Colorado Department of Natural Resources, Division of Water Resources, and the Colorado Water Conservation Board]

This report consists of a set of maps showing the structure, outcrop, and subcrop of the Laramie-Fox Hills, Arapahoe, Denver, and Dawson aquifers along about 100 miles of the western margin of the Denver Basin in Colorado.

Robson, S.G. and Heiny, J.S., 1998, Front Range Infrastructure Resources Project, WaterResources Activities: U.S. Geological Survey Fact Sheet 113-98, 4 p.

This fact sheet summarizes progress and preliminary results of water-resources work done as part of the Front Range Infrastructure Resources Project.

Robson, S.G., Arnold, L.R., and Heiny, J.S., 2000, Geohydrology of the shallow aquifers in the Greeley-Nunn area, Colorado: U.S. Geological Survey Hydrologic Investigations Atlas HA746A, 5 sheets, scale 1:50,000.

This report presents the results of a systematic mapping of the extent, thickness, and water-table altitude of the shallow aquifers in the Greeley-Nunn area, a 390-square-mile area in the Front Range urban corridor of northern Colorado. The report consists of 5 map sheets that show (1) the thickness and extent of the unconsolidated sediments that overlie bedrock formations in the area, (2) the altitude and configuration of the buried bedrock surface, (3) the altitude of the water table and direction of ground-water movement, (4) the saturated thickness of the shallow aquifers, and (5) the depth to the water table in the shallow aquifers.

Robson, S.G., Arnold, L.R., and Heiny, J.S., 2000, Geohydrology of the shallow aquifers in the Fort Collins-Loveland area, Colorado: U.S. Geological Survey Hydrologic Investigations Atlas HA-746B, 5 sheets, scale 1:50,000.

This report presents the results of a systematic mapping of the extent, thickness, and water-table altitude of the shallow aquifers in the Fort Collins-Loveland area, a 400-square-mile area in the Front Range urban corridor of northern Colorado. The report consists of 5 map sheets that show (1) the thickness and extent of the unconsolidated sediments that overlie bedrock formations in the area, (2) the altitude and configuration of the buried bedrock surface, (3) the altitude of the water table and direction of ground-water movement, (4) the saturated thickness of the shallow aquifers, and (5) the depth to the water table in the shallow aquifers.

Robson, S.G., Heiny, J.S., and Arnold, L.R., 2000, Geohydrology of the shallow aquifers in the Fort Lupton-Gilcrest area, Colorado: U.S. Geological Survey Hydrologic Investigations Atlas HA-746C, 5 sheets, scale 1:50,000.

This report presents the results of a systematic mapping of the extent, thickness, and water-table altitude of the 
shallow aquifers in the Fort Lupton-Gilcrest area, a 490-square-mile area in the Front Range urban corridor of northern Colorado. The report consists of 5 map sheets that show (1) the thickness and extent of the unconsolidated sediments that overlie bedrock formations in the area, (2) the altitude and configuration of the buried bedrock surface, (3) the altitude of the water table and direction of ground-water movement, (4) the saturated thickness of the shallow aquifers, and (5) the depth to the water table in the shallow aquifers.

Robson, S.G., Heiny, J.S., and Arnold, L.R., 2000, Geohydrology of the shallow aquifers in the Boulder-Longmont area, Colorado: U.S. Geological Survey Hydrologic Investigations Atlas HA-746D, 5 sheets, scale 1:50,000.

This report presents the results of a systematic mapping of the extent, thickness, and water-table altitude of the shallow aquifers in the Boulder-Longmont area, a 490-square-mile area in the Front Range urban corridor of northern Colorado. The report consists of 5 map sheets that show (1) the thickness and extent of the unconsolidated sediments that overlie bedrock formations in the area, (2) the altitude and configuration of the buried bedrock surface, (3) the altitude of the water table and direction of ground-water movement, (4) the saturated thickness of the shallow aquifers, and (5) the depth to the water table in the shallow aquifers.

\section{Reclamation, Habitat, and Environment}

Arbogast, B.F., 1998, Annotated bibliography of selected references on site design, environmental factors and regulations, and land use planning in mined land reclamation: USGS Open-File Report 98-144, 33p.

The purpose of this bibliography is to provide 1) a basic, first-stop resource on landscape architecture in mining reclamation which the non-specialist (i.e. public, students, geoscientists) can consult and 2) provide citations to original source of aggregate resource information for the specialist (including landscape architects, land planners, and mining industry).

Arbogast, B.F., 1999, Design approaches in quarrying and pit mining reclamation, in Johnson, K.S., ed., Proceedings, $34^{\text {th }}$ Forum on the Geology of Industrial Minerals, 2-6 May 1998, Norman, Oklahoma: Oklahoma Geological Survey Circular 102, p. 263-271.

\footnotetext{
An evaluation of reclaimed mine sites so that the public, industry, and land planners may recognize there are innovative designs available for consideration and use. Nine different approaches to designing post-mine sites are considered.
}

Arbogast, B.F., 2001, Using a vernacular language to present unfamiliar lexicons in mining and reclamation, in Symposium on the Application of Geophysics to Engineering and Environmental Problems (SAGEEP), Denver, Colo., 2001, Proceedings: Denver, Colo., Omnipress, CD-ROM, various pagination

The importance of using the common spoken language rather than unique subject vocabulary in communication with the public, government agencies, and industry is examined. Four disciplines for viewing mining and reclamation are compared: 1) architectural, 2) natural context, 3) social, and 4) cultural.

Arbogast, 2001, A review of reclamation law and the permitting process for surface mining in Colorado, in 37th Forum on the Geology of Industrial Minerals, Victoria, British Columbia, 2001, Program and Extended Abstracts: Victoria, British Columbia, British Columbia Ministry of Energy and Petroleum, p. 259. 


\begin{abstract}
Colorado legislation (at the State and local levels) is examined in relationship to the mineral resource industry. Attention is focused on four selected counties--Boulder, Clear Creek, Jefferson, and Weld.
\end{abstract}

Arbogast, B.F., in press, An overview of reclamation law dealing with mineral resource development in the United States of America, in Scott, P.W., and Bristow, C.M., eds., Industrial Minerals and Extractive Industry Geology, Proceedings of the 36th Forum on the Geology of Industrial Minerals and $11^{\text {th }}$ Extractive Industry Geology Conference, Bath, England, 2000: Bath, England, Geological Society Publishing House.

... This report focuses its examination of reclamation law to the broad federal statute standpoint and looks at regional differences by selecting states from ten different physiographic regions.

Arbogast, B.F., Knepper, D.H., Jr., and Langer, W.H., 1998, The human factor in mining reclamation: U.S. Geological Survey Open-File Report 98-523, 52p.

This report reviewed the literature for actual and proposed reclaimed mine sites and the human perception of mining. Varying definitions of landscape, historic perspective, and regulations are discussed.

Arbogast, B.F., Knepper, D.H., Jr., and Langer, W.H., 2000, The human factor in mining reclamation: U.S. Geological Survey Circular 1191, 28p. Available at URL http://greenwood.cr.usgs.gov/pub/circulars/c1191/

The circular is an updated color edition of the USGS Open-File Report 98-523. National and international examples of mine reclamation and public attitudes towards mining over the last 100 years are examined.

Arbogast, B., Knepper, D.H., Jr., Melick, R.A., and Hickman, J., 2001, Reading, remembering, and reshaping the past: Clear Creek, Colorado, in Kuula-Väisänen, Pirjo, and Uusinkoa, Raimo, eds., Proceedings, Aggregate 2001 - Environment and Economy, Helsinki, Finland, August 6-10, 2001: Tampere University of Technology, Laboratory of Engineering Geology, Publication No. 51, v. 2, p. 371-376.

Four symbolic landscape types associated with aggregate mining reclamation in the Denver metropolitan area are recognized: 1) water storage for large suburban areas, 2) wildlife/greenbelt systems, 3) water recreation, and 4) "hidden scenery."

Gladwin, D.N., and Roelle, J.E., 1999, Survival of plains cottonwood (Populus deltoides subsp. monilifera) and saltcedar (Tamarix ramosissima) seedlings in response to flooding: Wetlands, v. 18, no. 4, p. 669-674.

We examined the response of first-year saltcedar and plains cottonwood seedlings to flooding in the fall (25 days) and spring (28 days) using pot-grown plants (12-18 individuals/26.5-liter pot). Mean survival rates of seedlings flooded in fall (saltcedar $=0.8 \%$, cottonwood $=20.8 \%, \mathrm{n}=14$ pots) were lower compared to the spring flooding treatment $($ saltcedar $=91.1 \%$, cottonwood $=92.2 \%, \mathrm{n}=13)$ and control $($ saltcedar $=93.9 \%$, cottonwood $=98.7 \%, \mathrm{n}=$ 14). Smaller size and consequent lack of energy reserves may account for lower survival of saltcedar compared to cottonwood in the fall treatment, and for lower survival of both species in the fall treatment compared to the spring treatment. Fall flooding for controlling first year saltcedar seedlings may be a useful technique in riparian habitat restoration and management in the southwestern United States.

Gladwin, D.N., and Roelle, J.E., 1999, Survival of plains cottonwood and saltcedar seedlings in response to flooding, in Proceedings of the U.S. Geological Survey Front Range Infrastructure Resources Project Stakeholder's Meeting, 4 November 1998: U.S. Geological Survey Open-File Report 99-001, p.14-16.

This is a summary of Gladwin and Roelle (1999) above. 
Mladinich, C.S., 2000, The Clash of Titans - balancing the physical and human-induced environment for urban growth [abs.]: Presentation, Eleventh International Conference, The Society for Human Ecology, Jackson Hole, Wyoming, p. 35.

Roelle, J.E., and Gladwin, D.N., 1999, Establishment of woody riparian species from natural seedfall at a former gravel pit: Restoration Ecology, v. 7, no. 2, p.183-192.

\footnotetext{
At a gravel pit in Fort Collins, Colorado, we experimented with use of water-level manipulations and natural seedfall to induce establishment of native riparian species (plains cottonwood, peachleaf willow, and sandbar willow). In the 3 years of the study, frequency of occurrence on $0.5-\mathrm{m}^{2}$ sample plots ranged from $8.6 \%$ to $50.6 \%$ for cottonwood, $15.9 \%$ to $22.0 \%$ for peachleaf willow, and $21.7 \%$ to $50.0 \%$ for sandbar willow. Concurrent establishment of exotic and undesirable saltcedar also occurred, but we were able to eradicate most saltcedar seedlings by reflooding the lower elevations of the annual drawdown zone each fall. At the end of the 3-year period, at least one of the three native species survived on $41.1 \%$ of the plots, while saltcedar was present on only $6.1 \%$. In addition to the potential for establishing valuable native habitats, adaptations of the techniques described may require less earth moving than other reclamation approaches.
}

Roelle, J.E., and Gladwin, D.N., 1999, Establishment of woody riparian species at a former gravel pit, in Proceedings of the U.S. Geological Survey Front Range Infrastructure Resources Project Stakeholder's Meeting, 4 November 1998: U.S. Geological Survey OpenFile Report 99-001, p. 38-39.

This is a summary of Roelle and Gladwin (1999) above.

Roelle, J.E., Gladwin, D.N., and Cade, B.S., 2001, Establishment, growth, and early survival of woody riparian species in Colorado: Great Basin Naturalist, v. 61, no. 2, p. 192-194.

\footnotetext{
Presence of a wetted edge during the period of seedfall was an effective predictor of suitable establishment locations for plains cottonwood, peachleaf willow, sandbar willow, and the exotic saltcedar. At locations predicted to be suitable for establishment, position within the pit (possibly reflecting additional moisture provided by seepage) was a significant factor in determining whether establishment actually occurred. Cover of herbaceous species, which became established at the same time or after woody seedlings, was positively related to probability of establishment for 8 of 11 species-year combinations, probably reflecting more favorable moisture conditions at certain locations. Herbaceous cover was also positively related to seedling height at the end of the first summer of growth for 9 of 11 species-year combinations. Neither establishment nor first-summer growth was consistently related to overall decline in the water table. Flooding in the first spring after establishment was negatively related to subsequent survival for 5 of 8 species-year combinations.
}

Schroeder, R.L., McClean, Seth., and Lovell, Dave, 1999, Mapping and analyzing the relationship between habitat for the Preble's meadow jumping mouse and aggregate resources, in Proceedings of the U.S. Geological Survey Front Range Infrastructure Resources Project Stakeholder's Meeting, 4 November 1998: U.S. Geological Survey OpenFile Report 99-001, p.40-42.

The Preble's meadow jumping mouse (Zapus hudsonius preblei) is a federally threatened species that inhabits heavily vegetated riparian habitats in southeastern Wyoming and eastern Colorado along the Front Range. Much of the remaining habitat for the jumping mouse occurs in areas with known or potential aggregate resources (i.e., sand and gravel deposits). Riparian habitat was delineated in 25 quadrangles between Boulder and Colorado Springs. The Littleton quadrangle, used as an example, indicated that approximately $10 \%$ of the total area that contains the highest quality of known aggregate materials ( $\mathrm{T} 1$ and F1) has some type of riparian vegetation. 
U.S. Geological Survey, 2001, High-Resolution Land Use and Land Cover 1937/1938 Front Range Infrastructure Resources Project Demonstration Area, Rocky Mountain Mapping Center, Lakewood, Colo. Data available at URL http://rockyweb.cr.usgs.gov/frontrange/NMD/data/lu30.html (metadata) and http://rockyweb.cr.usgs.gov/frontrange/NMD/data/lu30.e00 (data).

This land use and land cover (LULC) data set was generated for the Front Range Infrastructure Resources (FRIR) Project. The data set covers the project's 45 1:24,000-scale quadrangle demonstration area that covers the Front Range of Colorado south from Ft. Collins to the southern portion of Denver metropolitan area (not including Highlands Ranch, Douglas County); and west from Denver International Airport to the eastern foothills of the Rocky Mountains. The data were collected from 1937/1938 USDA aerial photography using a Modified-Anderson Classification at a 2.5 -acre minimum mapping unit.

U.S. Geological Survey, 2001, High-Resolution Land Use and Land Cover 1953-1958 Front Range Infrastructure Resources Project Demonstration Area, Rocky Mountain Mapping Center, Lakewood, Colo. Data available at URL http://rockyweb.cr.usgs.gov/frontrange/NMD/data/lu50.html (metadata) and http://rockyweb.cr.usgs.gov/frontrange/NMD/data/lu50.e00 (data).

This land use and land cover (LULC) data set was generated for the Front Range Infrastructure Resources (FRIR) Project. The data set covers the project's 45 1:24,000-scale quadrangle demonstration area that covers the Front Range of Colorado south from Ft. Collins to the southern portion of Denver metropolitan area (not including Highlands Ranch, Douglas County); and west from Denver International Airport to the eastern foothills of the Rocky Mountains. The data were collected from 1953-1958 USGS and USDA aerial photography using a ModifiedAnderson Classification at a 2.5-acre minimum mapping unit.

U.S. Geological Survey, 2001, High-Resolution Land Use and Land Cover 1977/1978 Front Range Infrastructure Resources Project Demonstration Area, Rocky Mountain Mapping Center, Lakewood, Colo. Data available at URL http://rockyweb.cr.usgs.gov/frontrange/NMD/data/lu70.html (metadata) and http://rockyweb.cr.usgs.gov/frontrange/NMD/data/lu70.e00 (data).

This land use and land cover (LULC) data set was generated for the Front Range Infrastructure Resources (FRIR) Project. The data set covers the project's 45 1:24,000-scale quadrangle demonstration area that covers the Front Range of Colorado south from Ft. Collins to the southern portion of Denver metropolitan area (not including Highlands Ranch, Douglas County); and west from Denver International Airport to the eastern foothills of the Rocky Mountains. The data were collected from 1975, 1977-1978 USGS and USDA aerial photography using a ModifiedAnderson Classification at a 2.5-acre minimum mapping unit.

U.S. Geological Survey, 2001, High-Resolution Land Use and Land Cover 1996/1997 Front Range Infrastructure Resources Project Demonstration Area, Rocky Mountain Mapping Center, Lakewood, Colo. Data available at URL http://rockyweb.cr.usgs.gov/frontrange/NMD/data/lu90.html (metadata) and http://rockyweb.cr.usgs.gov/frontrange/NMD/data/lu90.e00 (data).

This land use and land cover (LULC) data set was generated for the Front Range Infrastructure Resources (FRIR) Project. The data set covers the project's 45 1:24,000-scale quadrangle demonstration area that covers the Front Range of Colorado south from Ft. Collins to the southern portion of Denver metropolitan area (not including Highlands Ranch, Douglas County); and west from Denver International Airport to the eastern foothills of the Rocky Mountains. The data were collected from 1996/1997 imagery using a Modified-Anderson Classification at a 2.5-acre minimum mapping unit.

\section{Digital Datasets}


Barnett, Adrienne, and Ellefsen, K.J., 2000, Assessment of the alluvial sediments in the Big Thompson River Valley, Colorado: U.S. Geological Survey Digital Data Series DDS-66, v.1.0. Data available on CDROM only.

To obtain subsurface geologic information about the alluvium in the Big Thompson River valley, S-wave refraction data were collected along three roads that cross the valley. The traveltimes were processed to estimate velocities and thickness for a layered-earth model; from these models, three cross sections of the river valley were constructed. A layer of soil 0.2 to $1.5 \mathrm{~m}$ thick covers the river. Beneath the soil, there is one layer of alluvium at some locations and two layers at other locations. For the two westernmost cross sections, the total thickness of the alluvium ranges from about 6 to $10 \mathrm{~m}$ near the center of the valley and from about 2 to $6 \mathrm{~m}$ near the sides of the valley. The easternmost cross section is somewhat more complex than the other two, because it is near the confluence of the Big Thompson and the Little Thompson Rivers. In this cross section, the thickness of the alluvium ranges from about 8 to $10 \mathrm{~m}$ in the southern half of the valley and from about 3 to $13 \mathrm{~m}$ in the northern half. In all three cross sections, the alluvium overlies bedrock, which is the upper transition member of the Pierre Shale.

Fishman, N.S., Evans, J.M., Olmstead, R.J., and Langer, W.H., 2000, 3-D image of urban areas and mountains of the northern Front Range, Colorado: U.S. Geological Survey Geologic Investigations Series I-2750-A, 4 page pamphlet, 1 sheet. Data available at URL http://greenwood.cr.usgs.gov/pub/i-maps/i-map2750-a/

Over the past 30 years, communities in the Northern Front Range of Colorado have experienced tremendous growth rivaling or surpassing that in other parts of the United States. This growth has challenged businesses as well as city, county, State, and Federal planners to meet the increasing demands for natural resources necessary for growth. Such resources include construction aggregate (stone, sand, and gravel), water, oil, and natural gas. This map will benefit the general public, businesses, and city, county, State and Federal agencies for a variety of purposes. Members of the Front Range Infrastructure Resources Project will use this 3-D image as a base map for companion publications that show the distribution of resources in the northern Front Range urban corridor and the effects of past resource extraction.

Higley, D.K., Pollastro, R.M., and Clayton, J.L., 1995, Denver Basin Province (039), in Gautier, D.L., Dolton, G.L., Takahashi, K.I., and Varnes, K.L., eds., 1995 National assessment of United States oil and gas resources on CD-ROM: U.S. Geological Survey Digital Data Series 30. Data available on CDROM and through URL http://greenwood.cr.usgs.gov/pub/dds/dds-030

Data files of the oil and gas assessment are available in self-extracting archives for Windows (1.8 MB) or Macintosh (3.1 MB) Each version includes text of the Executive Summary in MS Word format, JPEG images of maps and figures, and JPEG image viewing software. Note: the JPEG image viewing software included with each package are shareware programs from non-U.S. Government sources.

Knepper, D.H., Jr., Green, G.N., and Langer, W.H., 1999, Lithologic and aggregate attributes for the digital geologic map of Colorado: U.S. Geological Survey Open-File Report 99-29 (CDROM). Data are available on CDROM and at URL http://geology.cr.usgs.gov/pub/open-file-reports/ofr-99-0029/

The Geologic Map of Colorado (Tweto, 1979) was digitized and imported into ARC/INFO by Green (1992). The polygons containing each of the map units were attributed with a unique identification number for each map unit and the geologic symbol used to identify each unit and its age. To further increase the utility of the digital Geologic Map of Colorado, the digital data set has been reattributed to extend the capability of identifying natural aggregate potential to the entire State and expand the flexibility in searching for more specific lithologic characteristics. Two sets of attributes have been defined for the lithologic units contained on the Geologic Map of Colorado (Tweto, 1979). In addition to the identification number, map unit symbol, and age symbol based on Green (1992), the first set describes the mode of formation, composition, texture, and variability of the mapped units according to descriptions on the Explanation of the Geologic Map of Colorado. The second set estimates the physical and chemical properties of each unit for use as natural aggregate in Portland cement concrete and identifies other known uses of each unit for construction materials. 
Langer, W.H., Green, G.N., Knepper, D.H., Jr., Lindsey, D.A., Moore, D.W., Nealey, L.D., and Reed, J.C., 1997, Distribution and quality of potential sources of aggregate, Infrastructure Resources Project Area, Colorado and Wyoming: U.S. Geological Survey Open-File Report 97-477 (CDROM). Data are available on CDROM and at URL http://geology.cr.usgs.gov/pub/open-file-reports/ofr-97-0477/

This map was prepared by attributing the Digital Geologic Map of Colorado - USGS Open File Report 92-0507 with parameters reflecting the quality of unconsolidated materials and bedrock for use as aggregate (sand and gravel or crushed stone). Potential sources of aggregate are defined according to general physical and chemical quality. Physical quality is defined as satisfactory, fair, or poor. Chemical quality is defined as either innocuous or deleterious.

Schwochow, S.D., Shroba, R.R., and Wicklein, P.C., 1974, Atlas of sand, gravel, and quarry aggregate resources, Colorado Front Range Counties: Colorado Geological Survey Special Publication 5B, digitized and compiled by Cappa, J.A., Hiatt, C.S., Litke, D.W., McCormick, M.L., and Sadlick, Joseph, 2000, Colorado Geological Survey and U.S. Geological Survey Open-File Report 00-9 (CD-ROM). Data can be ordered on CDROM through the Colorado Geological Survey as OF00-09 at URL http://geosurvey.state.co.us/pubs/pub_list/publications_information.htm

The digital dataset on this CD-ROM is a representation of the Colorado Geological Survey's Special Publication 5A/5B entitled, "Sand, Gravel, and Quarry Aggregate Resources, Colorado Front Range Counties" by Schwochow, Shroba, and Wicklein, published in 1974.

Robson, S.G., 1996, Geohydrology of the shallow aquifers in the Denver metropolitan area, Colorado: U.S. Geological Survey Hydrologic Investigations Atlas HA-736, 5 sheets, scale 1:50,000. Data available at URL http://webserver.cr.usgs.gov/frirp/water_project/shaqpage.html

\footnotetext{
This report presents the results of a systematic mapping of the extent, thickness, and water-table altitude of the shallow aquifers in a 700-square-mile part of the greater Denver metropolitan area in Colorado. The report consists of 5 map sheets that show (1) the thickness and extent of the unconsolidated sediments that overlie bedrock formations in the area, (2) the altitude and configuration of the buried bedrock surface, (3) the altitude of the water table and direction of ground-water movement, (4) the saturated thickness of the shallow aquifers, and (5) the depth to the water table in the shallow aquifers.
}

Robson, S.G., Van Slyke, George, and Graham, Glenn, 1998, Structure, outcrop, and subcrop of the bedrock aquifers along the western margin of the Denver Basin, Colorado: U.S. Geological Survey Hydrologic Investigations Atlas HA-742, 5 sheets, scale 1:50,000. [Prepared in cooperation with the Colorado Department of Natural Resources, Division of Water Resources, and the Colorado Water Conservation Board]. Data available through URL http://water.usgs.gov/public/GIS/

\footnotetext{
This report consists of a set of maps showing the structure, outcrop, and subcrop of the Laramie-Fox Hills, Arapahoe, Denver, and Dawson aquifers along about 100 miles of the western margin of the Denver Basin in Colorado.
}

Robson, S.G., Arnold, L.R., and Heiny, J.S., 2000, Geohydrology of the shallow aquifers in the Greeley-Nunn area, Colorado: U.S. Geological Survey Hydrologic Investigations Atlas HA746A, 5 sheets, scale 1:50,000. Digital dataset in preparation as of September 2001; hardcopy available through the U.S. Geological Survey.

This report presents the results of a systematic mapping of the extent, thickness, and water-table altitude of the shallow aquifers in the Greeley-Nunn area, a 390-square-mile area in the Front Range urban corridor of northern Colorado. The report consists of 5 map sheets that show (1) the thickness and extent of the unconsolidated sediments that overlie bedrock formations in the area, (2) the altitude and configuration of the buried bedrock surface, (3) the 
altitude of the water table and direction of ground-water movement, (4) the saturated thickness of the shallow aquifers, and (5) the depth to the water table in the shallow aquifers.

Robson, S.G., Arnold, L.R., and Heiny, J.S., 2000, Geohydrology of the shallow aquifers in the Fort Collins-Loveland area, Colorado: U.S. Geological Survey Hydrologic Investigations Atlas HA-746B, 5 sheets, scale 1:50,000. Digital dataset in preparation as of September 2001; hardcopy available through the U.S. Geological Survey.

\footnotetext{
This report presents the results of a systematic mapping of the extent, thickness, and water-table altitude of the shallow aquifers in the Fort Collins-Loveland area, a 400-square-mile area in the Front Range urban corridor of northern Colorado. The report consists of 5 map sheets that show (1) the thickness and extent of the unconsolidated sediments that overlie bedrock formations in the area, (2) the altitude and configuration of the buried bedrock surface, (3) the altitude of the water table and direction of ground-water movement, (4) the saturated thickness of the shallow aquifers, and (5) the depth to the water table in the shallow aquifers.
}

Robson, S.G., Heiny, J.S., and Arnold, L.R., 2000, Geohydrology of the shallow aquifers in the Fort Lupton-Gilcrest area, Colorado: U.S. Geological Survey Hydrologic Investigations Atlas HA-746C, 5 sheets, scale 1:50,000. Digital dataset in preparation as of September 2001; hardcopy available through the U.S. Geological Survey.

\footnotetext{
This report presents the results of a systematic mapping of the extent, thickness, and water-table altitude of the shallow aquifers in the Fort Lupton-Gilcrest area, a 490-square-mile area in the Front Range urban corridor of northern Colorado. The report consists of 5 map sheets that show (1) the thickness and extent of the unconsolidated sediments that overlie bedrock formations in the area, (2) the altitude and configuration of the buried bedrock surface, (3) the altitude of the water table and direction of ground-water movement, (4) the saturated thickness of the shallow aquifers, and (5) the depth to the water table in the shallow aquifers.
}

Robson, S.G., Heiny, J.S., and Arnold, L.R., 2000, Geohydrology of the shallow aquifers in the Boulder-Longmont area, Colorado: U.S. Geological Survey Hydrologic Investigations Atlas HA-746D, 5 sheets, scale 1:50,000. Digital dataset in preparation as of September 2001; hardcopy available through the U.S. Geological Survey.

\footnotetext{
This report presents the results of a systematic mapping of the extent, thickness, and water-table altitude of the shallow aquifers in the Boulder-Longmont area, a 490-square-mile area in the Front Range urban corridor of northern Colorado. The report consists of 5 map sheets that show (1) the thickness and extent of the unconsolidated sediments that overlie bedrock formations in the area, (2) the altitude and configuration of the buried bedrock surface, (3) the altitude of the water table and direction of ground-water movement, (4) the saturated thickness of the shallow aquifers, and (5) the depth to the water table in the shallow aquifers.
}

U.S. Geological Survey, 2001, High-Resolution Land Use and Land Cover 1937/1938 Front Range Infrastructure Resources Project Demonstration Area, Rocky Mountain Mapping Center, Lakewood, Colo. Data available at URL http://rockyweb.cr.usgs.gov/frontrange/NMD/data/lu30.html (metadata) and http://rockyweb.cr.usgs.gov/frontrange/NMD/data/lu30.e00 (data).

This land use and land cover (LULC) data set was generated for the Front Range Infrastructure Resources (FRIR) Project. The data set covers the project's 45 1:24,000-scale quadrangle demonstration area that covers the Front Range of Colorado south from Ft. Collins to the southern portion of Denver metropolitan area (not including Highlands Ranch, Douglas County); and west from Denver International Airport to the eastern foothills of the Rocky Mountains. The data were collected from 1937/1938 USDA aerial photography using a Modified-Anderson Classification at a 2.5 -acre minimum mapping unit.

U.S. Geological Survey, 2001, High-Resolution Land Use and Land Cover 1953-1958 Front Range Infrastructure Resources Project Demonstration Area, Rocky Mountain Mapping Center, Lakewood, Colo. Data available at URL http://rockyweb.cr.usgs.gov/frontrange/NMD/data/lu50.html (metadata) and http://rockyweb.cr.usgs.gov/frontrange/NMD/data/lu50.e00 (data). 
This land use and land cover (LULC) data set was generated for the Front Range Infrastructure Resources (FRIR) Project. The data set covers the project's 45 1:24,000-scale quadrangle demonstration area that covers the Front Range of Colorado south from Ft. Collins to the southern portion of Denver metropolitan area (not including Highlands Ranch, Douglas County); and west from Denver International Airport to the eastern foothills of the Rocky Mountains. The data were collected from 1953-1958 USGS and USDA aerial photography using a Modified-

Anderson Classification at a 2.5-acre minimum mapping unit.

U.S. Geological Survey, 2001, High-Resolution Land Use and Land Cover 1977/1978 Front Range Infrastructure Resources Project Demonstration Area, Rocky Mountain Mapping Center, Lakewood, Colo. Data available at URL http://rockyweb.cr.usgs.gov/frontrange/NMD/data/lu70.html (metadata) and http://rockyweb.cr.usgs.gov/frontrange/NMD/data/lu70.e00 (data).

This land use and land cover (LULC) data set was generated for the Front Range Infrastructure Resources (FRIR) Project. The data set covers the project's 45 1:24,000-scale quadrangle demonstration area that covers the Front Range of Colorado south from Ft. Collins to the southern portion of Denver metropolitan area (not including Highlands Ranch, Douglas County); and west from Denver International Airport to the eastern foothills of the Rocky Mountains. The data were collected from 1975, 1977-1978 USGS and USDA aerial photography using a Modified-

Anderson Classification at a 2.5-acre minimum mapping unit.

U.S. Geological Survey, 2001, High-Resolution Land Use and Land Cover 1996/1997 Front Range Infrastructure Resources Project Demonstration Area, Rocky Mountain Mapping Center, Lakewood, Colo. Data available at URL http://rockyweb.cr.usgs.gov/frontrange/NMD/data/lu90.html (metadata) and http://rockyweb.cr.usgs.gov/frontrange/NMD/data/lu90.e00 (data).

This land use and land cover (LULC) data set was generated for the Front Range Infrastructure Resources (FRIR) Project. The data set covers the project's 45 1:24,000-scale quadrangle demonstration area that covers the Front Range of Colorado south from Ft. Collins to the southern portion of Denver metropolitan area (not including Highlands Ranch, Douglas County); and west from Denver International Airport to the eastern foothills of the Rocky Mountains. The data were collected from 1996/1997 imagery using a Modified-Anderson Classification at a 2.5-acre minimum mapping unit. 